\title{
Revisiting the extended Svalbard Airport monthly temperature series, and the compiled corresponding daily series 1898-2018
}

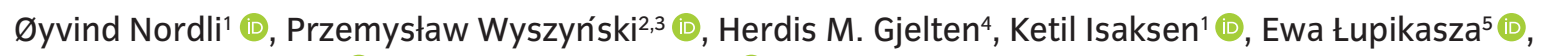 \\ Tadeusz Niedźwiedź ${ }^{5}$ (1) \& Rajmund Przybylak ${ }^{2,3}$ (1) \\ 'Department of Research and Development, Norwegian Meteorological Institute, Oslo, Norway; \\ ${ }^{2}$ Faculty of Earth Sciences and Spatial Management, Nicolaus Copernicus University, Toruń, Poland; \\ ${ }^{3}$ Centre for Climate Change Research, Nicolaus Copernicus University, Toruń, Poland; \\ ${ }^{4}$ Observation and Climate Department, Norwegian Meteorological Institute, Oslo, Norway; \\ ${ }^{5}$ Institute of Earth Sciences, University of Silesia in Katowice, Sosnowiec, Poland
}

\begin{abstract}
The Svalbard Airport composite series spanning the period from 1898 to the present represents one of very few long-term instrumental temperature series from the High Arctic. A homogenized monthly temperature series is available since 2014. Here we increase the resolution from a monthly to daily basis, and further digitization of historical data has reduced the uncertainty of the series. The most pronounced changes in the 120-year record occur during the last three decades. For the 1991-2018 period the number of days warmer than 0 and $5{ }^{\circ} \mathrm{C}$ has increased by $25(21 \%)$ and $22(59 \%)$, respectively, per year compared to the 1961-1990 standard normal. Likewise, comparing the same periods, the number of days colder than -10 and $-20{ }^{\circ} \mathrm{C}$ has decreased by $42(32 \%)$ and $27(62 \%)$, respectively. During the entire time span of the series, the western Spitsbergen climate has gone through stepwise changes, alternating between cold and warm regimes: 1899-1929 was cold, 1930-1961 warm, 1962-1998 cold and 1999-2018 warm. The latest cold regime was $1.0^{\circ} \mathrm{C}$ warmer than the first cold one, and the latest warm regime was $1.7^{\circ} \mathrm{C}$ warmer than the previous warm one. For the whole series the linear trend for annual means amounts to $0.32^{\circ} \mathrm{C} /$ decade, which is about 3.5 times the increase of the global mean temperature for the same period. Since 1991, the rate of warming at Svalbard Airport is $1.7^{\circ} \mathrm{C} /$ decade, which is more than twice the Arctic average $\left(0.8{ }^{\circ} \mathrm{C} /\right.$ decade, north of $\left.66^{\circ} \mathrm{N}\right)$ and about seven times the global average for the same period.
\end{abstract}

To access the supplementary material, please visit the article landing page

\section{Keywords}

Arctic warming; Arctic climate; Svalbard climate; Artic temperature trends; climate threshold statistics; Svalbard climate regimes

\section{Correspondence}

Øyvind Nordli, Norwegian Meteorological Institute, P.O. Box 43, 0313 Oslo, Norway. E-mail: peron@met.no

\section{Abbreviations}

AFI: air freezing index (see Table 4) ATI: air thawing index (see Table 4) AWAKE: Arctic Climate and Environment of the Nordic Seas and the Svalbard-Greenland Area project

DJF: December-February (winter)

FD: freeze days (see Table 4)

GD: growing days (see Table 4) GDD: growing degree-days (see Table 4) GISTEMP: Goddard's Global Surface Temperature Analysis data set, US National Aeronautical and Space Administration JJA: June-August (summer)

IP4: inverse proportionality with four corrections

MAM: March-May (spring)

MD: melt days (see Table 4)

MET Norway: Norwegian Meteorological Institute

PDD: positive degree-days (see Table 4) RMSE: root mean square error

SON: September-November (autumn) SSR/SST: the ratio of the regression sum of squares to the total sum of squares without using the regression

TD: thawing days (see Table 4)

\section{Introduction}

At Svalbard Airport, a continuous temperature series exists for the period starting 1 August 1975. The Airport is close to Longyearbyen, along the fjord Isfjorden, where several older series are also available (Fig. la). By combining these series-including observations made by hunting and scientific expeditions-a homogenized, composite monthly mean temperature time series for Svalbard Airport has been extended back to July 1898 (Nordli et al. 2014). The present revisit is motivated by the fact that the series is frequently used by scientists from different disciplines (e.g., Gjelten et al. 2016; Isaksen et al. 2016; Descamps et al. 2017; Hamilton et al. 2018; Hegerl et al. 


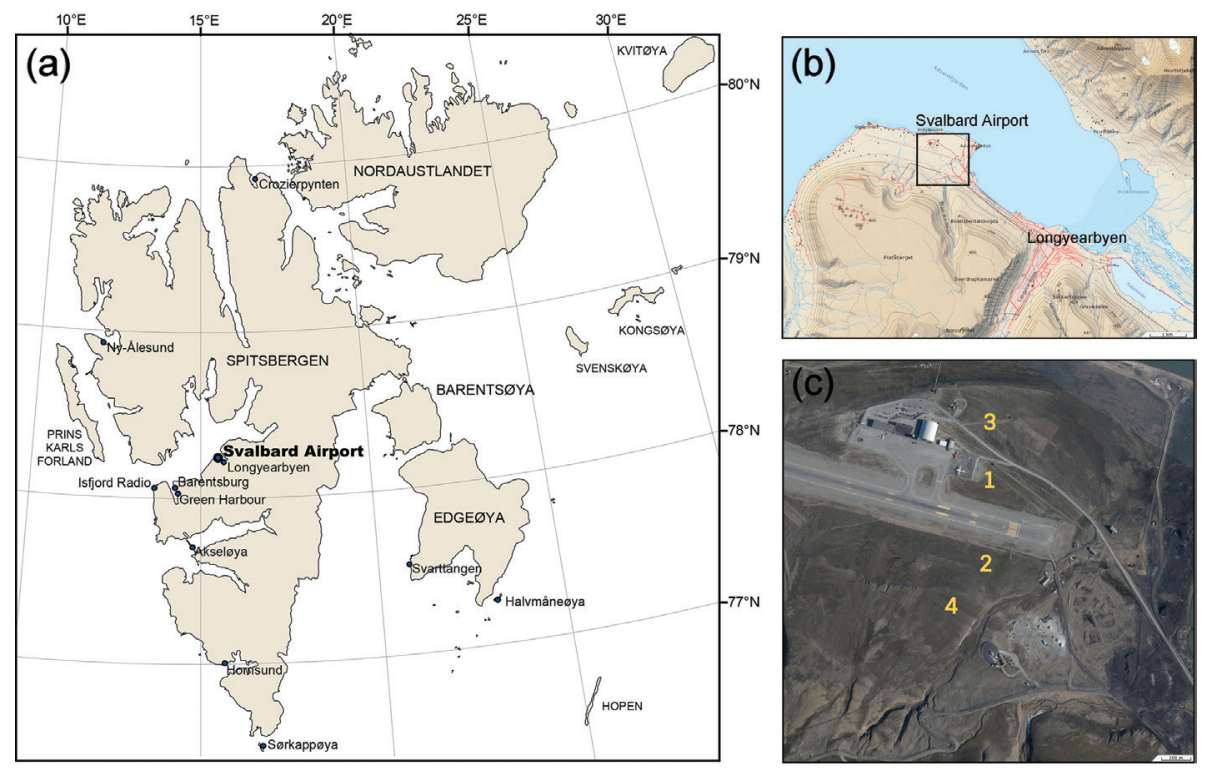

Fig. 1 (a) Map of the northern part of Svalbard showing the sites of historical and present-day meteorological stations referred to in this article. (b) Map of the Svalbard Airport and Longyearbyen area. (c) Part of the runway of Svalbard Airport. The numbers represent measuring sites during the parallel measurement campaign conducted from 22 September 2015-20 July 2016. Site 1 was the official station before the relocation and site 2 the official station after the relocation (see the supplementary material). (Maps from TopoSvalbard, Norwegian Polar Institute.)

2018; Osmont et al. 2018; Pramanik et al. 2018; Woelders et al. 2018; Ewertowski et al. 2019). The article by Nordli et al. (2014) has been cited more than 100 times and was the most cited paper in the journal Polar Research in the five years following its publication. Further motivation for revisiting the data is that more historical temperature series have been digitized since 2012, enabling both better data control and increased resolution from a monthly to daily basis.

Increasing concentrations of greenhouse gases in the atmosphere are the dominant contributor to the recent Arctic warming (Fyfe et al. 2013). The heat trapped by greenhouse gases triggers a cascade of feedbacks that collectively amplify Arctic warming (AMAP 2017). These feedbacks include reduction of the sea-ice cover and thereby cause increased release of heat to the atmosphere (Overland \& Wang 2010; Overland et al. 2011; Alekseev et al. 2016), increased content of water vapour (Park et al. 2015), cloud conditions (Graversen et al. 2014; Pithan \& Mauritsen 2014), in addition to other drivers such as increased sea-surface temperature (Serreze et al. 2011) and inflow of warm Atlantic Water (Overland \& Serreze 2012). Daily data are important for the assessment of, for example, trends in daily-based climate indices, and the study of local factors and feedback mechanisms related to Arctic amplification, which are still not fully understood (Stuecker et al. 2018).

In Svalbard, as in the whole Arctic, the most recent years are the warmest in the instrumental records
(Gjelten et al. 2016). The average annual air temperature for Svalbard for the 30 years between 1988 and 2017 was $1.5^{\circ} \mathrm{C}$ higher than it was during the reference period 1971-2000 (Hanssen-Bauer et al. 2019). Since the beginning of the 21 st century, the deviations of seasonal air temperatures from the long-term average of 18982017 were all positive for successive years (Łupikasza \& Niedźwiedź 2019). Compared to the Early 20th Century Warming, the current warming is stronger (e.g., Gjelten et al. 2016; Łupikasza \& Niedźwiedź 2019) and persists over the whole Arctic region.

Moreover, the diminishing sea-ice cover in the fjords contributes to increased temperature locally, especially during the winter months after 2006 (Muckenhuber et al. 2016). The increase in temperature after 2000 is primarily driven by the retreat of sea ice, along with higher sea temperatures and a general background warming (Isaksen et al. 2016).

The extended homogenized Svalbard Airport temperature series of daily values is our contribution to research that needs to be seen from a historical perspective. For example, the series makes it possible to study long-term variations of threshold statistics that are important for monitoring wildlife, and for understanding how warm winter spells affect the land surface and how building foundations may be affected by thawing permafrost. The new data series, both monthly and daily values, are accessible as a supplementary data set with this article. 
The series will also be stored in the Climate Data Base of MET Norway, where all data are freely available on its website https://www.met.no/ with reference to this article.

\section{Methods, data and metadata}

\section{Regression analysis}

The Svalbard Airport composite series is based on direct observations made at Svalbard Airport over a time period ranging from 1975 to the present, which we will call the principal series. Before 1975, it was a composite series consisting of many local series. The composite is established by two steps: (1) quality checking and homogenizing the local series; (2) adjusting the local series to ensure their comparability with the principal series (the Svalbard Airport site). The local series were checked by using the Standard Normal Homogeneity Test introduced by Alexandersson (1986). This is a relative homogeneity test that requires reference stations for comparison. However, the number of reference stations is sparse in Svalbard, so taking metadata into account is even more important in this context than when working with denser networks. During some periods, the neighbouring stations are so remote that the analysis of the metadata is the only real homogeneity test. Inhomogeneities in a data series might be due to radiation screen changes, changed observational procedures, site relocations, etc. After finishing the first step, a network was available in which the principal series as well as the local series were considered to be homogeneous. In the second step, the local series were adjusted to be directly comparable with the principal series based on regression analysis. The daily mean temperature of the principal series, $T_{S^{\prime}}$ can be written as:

$$
T_{s}=\alpha_{1} T_{A}+C_{1}+e_{A}
$$

where $T_{A^{\prime}}$ is the daily mean temperature of a local series A that partly overlaps the principal series, $\alpha_{1}$ and $C_{1}$ are constants calculated by using the least square method, and $e_{\mathrm{A}}$ represents noise (residuals). The predicted daily mean temperature of the principle series, $\hat{T}_{s}$, is given by Eqn. (2):

$$
\hat{T}_{s}=\alpha_{1} T_{A}+C_{1}
$$

In some time intervals, more than one local series were candidates for use in the composite Svalbard Airport series. In such cases, we chose the one that correlated best with the principal series.
The residual, $e$, representing the noise in Eqn. 1, is the RMSE. Another measure of the usefulness of the regression is the ratio SSR/SST, in which SSR is the regression sum of squares and SST is the total sum of squares without using the regression. This ratio shows how much of the variance is accounted for by the regression (Wilks 1995).

\section{Smoothing of the series}

In order to study variations on selected time scales the time series were smoothed by means of a Gaussian filter:

$$
G_{j}=\frac{\sum_{i=1}^{n} w_{i j} \cdot x_{i}}{\sum_{i=1}^{n} w_{i j}}, \text { where } w_{i j}=\exp \frac{-(i-j)^{2}}{2 s^{2}}
$$

$G_{j}$ is the value of the smoothed series in year $j, x_{i}$ is the data point in year $i, w_{j}$ is the weight in year $j, n$ is the number of years in the series and $s$ is the standard deviation in the Gaussian distribution. The degree of smoothing is established by the value of the standard deviation in the distribution; for example, a standard deviation of three years corresponds to an approximately 10-year rectangular low-pass filter.

\section{Regime shifts}

Climate data series may also contain regime shifts (step changes) or a blending of steps and trends (Corti et al. 1999). However, interpretations of data in terms of steps and trends depend to an extent on what results are expected, and the scientific background of any particular researcher (BACC Author Team 2008:14). For the detection of regime shifts a sequential data processing technique, introduced by Rodionov (2004), was used. The testing procedure works as follows: for each new observation a test is performed to determine the validity of the null hypothesis, HO (the existence of a regime shift). There are three possible outcomes of the test: accept H0, reject HO or keep on testing. In order to decide whether two subsequent regimes were significantly different, Student's test with significance level $p=0.05$ was used. Testing was continued with the entire data set over the period 1899-2018, now by using a newer version of the Rodionov test. This version is designed to handle detection of regime shifts in data sets with autocorrelations by using a so-called prewhitening by the IP4 procedure (Rodionov 2006). We also slightly reduced the influence of outliers by using the Huber tuning constant (Huber 1981), which was set to 2 . Before testing it is necessary to set a cut-off 
length, which roughly determines the minimum length of what is accepted as a regime. As was done by Nordli et al. (2014), the cut-off length was set to 10 years.

\section{Metadata and data}

A comprehensive description of the station data and metadata was given by Nordli et al. (2014), so this need not be repeated here. However, since 2014, more data have become available, and metadata have been updated for some stations, as shown in the following text.

Longyearbyen. For years, the data protocols for the Longyearbyen station seemed to have been lost. There existed only old, manually calculated monthly means. Parts of the Svalbard monthly composite series were based on these old data. A further search for the protocols in 2017 and 2018 was successful, so now additional daily data have been digitized for the period 1916-1939. The Longyearbyen series has higher priority than any other local series for inclusion in the composite series, but unfortunately there are many gaps in the Longyearbyen series (Table 1, Fig. 2).

Isfjord Radio. A data logger was in operation at the historical site in the period September 1996-December 2004, and in August 2014 MET Norway opened an official meteorological station at the site. Both data periods are used for developing the regression equation homogenizing Isfjord Radio data for the composite series. Periods in the interval January 1934-November 1947 are used (Table 1, Fig. 2).

Akseløya and Sørkappøya. These started as AWAKE research project stations but were later incorporated into MET Norway's ordinary station network. This increases the overlapping period with the principle series from about three to eight years. Akseløya is the station that contributes to the earliest interval of the composite series (Table 1, Fig. 2).

Svalbard Airport. The temperature screen at Svalbard Airport was relocated on 18 September 2016. Parallel measurements were carried out for the detection of a possible inhomogeneity by the relocation, but no corrections were found to be necessary. The measurements are discussed in detail in the supplementary material.

\section{Results}

Altogether, we used nine different local series in the composite series (Fig. 2). There are many gaps in the series, so the inclusion often shifts from one local series to another; see the "inclusion" column in Table 1. Some of the local series had periods of only two years that overlapped with the principal series when the original article was written (Nordli et al. 2014). Since then, the included series from Akseløya, Sørkappøya and Isfjord Radio have continued to be used even in the present, so the overlapping periods have now increased (Table 1). New and statistically more significant regression equations replaced the old ones for these local stations (Table 2).

\section{Evaluation of the uncertainty and variance}

To evaluate the results, we used two measures (Table 2). The RMSE is often used as a measure for uncertainties in a regression model. Another measure-the SSR/SST ratio-tells how much of the variance is accounted for by the regression. It turns out that the quality of the regression varies throughout the year.

Winter, spring and autumn. The uncertainty is largest in these seasons, RMSE amounts to $1-2{ }^{\circ} \mathrm{C}$ for most of the stations, but it is less than $1{ }^{\circ} \mathrm{C}$ for the Longyearbyen station, which lies only $4 \mathrm{~km}$ from the measuring site at the Airport. For the stations outside western Spitsbergen such as Sørkappøya, Crozierpynten and Svarttangen the RMSE exceeds $2{ }^{\circ} \mathrm{C}$ for many of the months. The variance accounted for by the regression is as high as about $95 \%$ for most of the stations but is less for the three stations already mentioned lying outside western Spitsbergen. The modelled temperatures based on Longyearbyen, however, are remarkable: the regression accounts for 99\% of the variance in January, February, March, October and November.

Summer. The RMSE is low for June, July and August. This is due to very low variability in the Arctic summer temperature rather than because of the quality of the model. This is seen by studying the SSR/SST ratio, which for many of the stations is about $80-90 \%$. For Sørkappøya, Crozierpynten and Svarttangen, however, the SSR/ SST ratios are very low. Because such a small part of the variance is accounted for by the regression we have omitted the summer months for these particular stations in the composite series of daily means.

After calculating and applying regression equations, the Svalbard Airport series is available as predictions in the period September 1898-July 1975, and as observations in the period August 1975-December 2018.

\section{Evaluation of maxima and minima}

The series is shown in Fig. 3 for both annual and seasonal values. Looking first at the individual means (annual or seasonal), the lowest temperatures are usually found in the early part of the series, except for autumn, in which there is a cluster of cold years in the late 1960s. The highest temperatures 
Table 1 The nine local series used in the composite Svalbard series.

\begin{tabular}{|c|c|c|c|c|}
\hline Code $^{a}$ & Series $^{b}$ & Overlapping ${ }^{c}$ & Status $^{d}$ & Inclusione \\
\hline 0 & 99840 Svalbard Airport & & & 1975.07.01-present \\
\hline \multirow[t]{9}{*}{1} & 99860 Longyearbyen & 1975.08-1977.07 & No & $1911.08 .16-1912.06 .30$ \\
\hline & & & & $1916.11 .01-1919.09 .30$ \\
\hline & & & & $1919.11 .01-1920.05 .31$ \\
\hline & & & & 1921.09.20-1923.09.01 \\
\hline & & & & $1930.09 .01-1934.08 .31$ \\
\hline & & & & 1935.02.01-1935.09.30 \\
\hline & & & & $1936.11 .01-1939.06 .30$ \\
\hline & & & & $1945.09 .01-1946.08 .31$ \\
\hline & & & & $1957.01 .01-1975.06 .30$ \\
\hline \multirow[t]{4}{*}{2} & 99820 Barentsburg & 1975.08-2012.12 & No & 1934.09.01-1935.01.31 \\
\hline & & & & $1935.10 .01-1935.12 .31$ \\
\hline & & & & 1940.01.01-1941.07.31 \\
\hline & & & & $1947.12 .01-1956.12 .31$ \\
\hline \multirow[t]{3}{*}{3} & 99790 Isfjord Radio & 1975.08-1976.07 & Yes & 1936.01.01-1936.10.31 \\
\hline & & 1996.09-2004.12 & & 1939.07.01-1939.12.31 \\
\hline & & 2014.09-2018.12 & & $1946.09 .01-1947.11 .30$ \\
\hline \multirow[t]{5}{*}{4} & 99765 Akseløya & 2010.09-2018.12 & Yes & $1898.09 .01-1899.08 .08$ \\
\hline & & & & 1900.09.01-1901.07.02 \\
\hline & & & & 1902.09.01-1903.07.10 \\
\hline & & & & $1904.09 .01-1905.06 .30$ \\
\hline & & & & 1910.09.01-1911.06.17 \\
\hline \multirow[t]{3}{*}{5} & 99737 Svarttangen & 2010.09-2012.06 & No & 1905.07.01-1905.08.19 \\
\hline & & & & 1906.10.21-1907.07.31 \\
\hline & & & & 1909.05.01-1909.07.19 \\
\hline \multirow[t]{2}{*}{6} & 99732 Halvmåneøya & & & 1906.09.15-1906.10.20 \\
\hline & & & & 1907.08.01-1907.08.31 \\
\hline 7 & 99928 Crozierpynten & 2010.07-2012.06 & No & 1899.08.09-1900.08.15 \\
\hline \multirow[t]{4}{*}{8} & 99821 Green Harbour & & No & 1912.07.01-1916.10.31 \\
\hline & & & & 1919.10.01-1919.10.31 \\
\hline & & & & 1920.06.01-1921.09.19 \\
\hline & & & & $1923.09 .02-1930.08 .31$ \\
\hline 9 & 99752 Sørkappøуa & 2010.10-2018.12 & Yes & 1908.09.01-1909.04.30 \\
\hline \multirow[t]{7}{*}{10} & Gaps in the series & & No & 1901.07.03-1902.08.31 \\
\hline & & & & 1903.07.11-1904.08.31 \\
\hline & & & & 1905.08.20-1906.09.14 \\
\hline & & & & 1907.09.01-1908.08.31 \\
\hline & & & & 1909.07.20-1910.08.31 \\
\hline & & & & 1911.06.02-1911.08.07 \\
\hline & & & & $1941.08 .01-1945.08 .31$ \\
\hline
\end{tabular}

${ }^{\mathrm{a}} 1-9$ identify the local series; code 0 is the principle series. ${ }^{\mathrm{b}}$ The national station identifiers and names. ${ }^{\mathrm{c} C o m m o n}$ data periods between the local series and the principle series. ${ }^{d}$ Whether the additional data prolongs the overlapping period since the publication by Nordli et al. (2014). ${ }^{e}$ Data period included in the composite series.

are found in the most recent years; for example, seven very warm years occurred consecutively in the period 2012-18. Among these, 2016 stands out as being particularly warm; it was in fact the warmest year in the whole composite series and had an annual mean temperature of $0{ }^{\circ} \mathrm{C}$. This year also includes the highest mean spring temperature.

The summer of 1922 is an example of a high temperature relatively early in the series, and the summer of 1899 is remarkably warm. Thirty percent of the data for the 1899 summer is from reanalysis and $70 \%$ from regression with Akseløya. The part from Akseløya does not have an uncertainty greater than for most of the series, so even with the $30 \%$ included from the reanalysis, the 1899 summer mean is considered quite reliable. However, looking at the whole series, all warm extremes (annual as well as seasonal) are found in the 21 st century. 
Table 2 Regressions between Svalbard Airport principle series and local series of daily mean temperature.

\begin{tabular}{|c|c|c|c|c|c|c|c|c|c|c|c|c|}
\hline Coefficient & Jan & Feb & Mar & Apr & May & Jun & Jul & Aug & Sep & Oct & Nov & Dec \\
\hline \multicolumn{13}{|c|}{ Svalbard Airport—Longyearbyen (1975-77) } \\
\hline$\alpha^{\mathrm{a}}$ & 1.018 & 1.038 & 1.036 & 1.023 & 1.049 & 0.976 & 1.022 & 0.929 & 0.970 & 0.968 & 0.971 & 1.023 \\
\hline$C^{a}$ & -0.52 & -0.68 & -0.88 & -1.13 & -1.10 & -0.87 & -1.01 & -0.26 & -0.57 & -0.21 & -0.36 & -0.04 \\
\hline SSR/SST ${ }^{b}(\%)$ & 99 & 99 & 99 & 98 & 98 & 96 & 90 & 92 & 97 & 99 & 99 & 98 \\
\hline RMSE $^{c}$ & -0.7 & -0.9 & -1.1 & -0.8 & -0.6 & -0.6 & -0.7 & -0.5 & -0.4 & -0.5 & -0.6 & -1.2 \\
\hline$\alpha^{a}$ & 1.087 & 1.089 & 1.068 & 1.059 & 1.048 & 1.018 & 0.988 & 1.031 & 1.083 & 1.100 & 1.096 & 1.082 \\
\hline$C^{a}$ & 0.10 & 0.22 & 0.15 & 0.15 & 0.47 & 0.53 & 0.49 & 0.16 & -0.06 & 0.11 & 0.21 & 0.04 \\
\hline SSR/SST ${ }^{b}(\%)$ & 94 & 94 & 93 & 94 & 95 & 90 & 84 & 87 & 93 & 94 & 95 & 95 \\
\hline RMSE $^{c}$ & 2.1 & 2.1 & 2.2 & 1.6 & 0.9 & 0.8 & 0.9 & 0.8 & 0.9 & 1.2 & 1.5 & 1.7 \\
\hline \multicolumn{13}{|c|}{ Longyearbyen-Green Harbour (1911-1930) } \\
\hline$\alpha^{\mathrm{a}}$ & 0.917 & 0.881 & 0.822 & 0.902 & 0.996 & 1.002 & 1.002 & 1.002 & 1.051 & 0.927 & 0.945 & 0.829 \\
\hline SSR/SST ${ }^{b}(\%)$ & 96 & 90 & 92 & 92 & 94 & 78 & 78 & 78 & 89 & 84 & 92 & 91 \\
\hline RMSE $^{\mathrm{c}}$ & 2.4 & 2.9 & 2.6 & 2.2 & 1.2 & 1.6 & 1.3 & 1.1 & 1.1 & 1.8 & 2.1 & 2.7 \\
\hline \multicolumn{13}{|c|}{ Longyearbyen-Isfjord Radio (1957-1977) } \\
\hline$\alpha^{\mathrm{a}}$ & 1.173 & 1.182 & 1.159 & 1.143 & 1.119 & 1.206 & 0.982 & 1.118 & 1.174 & 1.224 & 1.205 & 1.184 \\
\hline$C^{a}$ & -0.53 & -0.55 & -0.25 & -0.00 & 0.62 & 0.96 & 1.80 & 0.55 & -0.10 & -0.57 & -0.49 & -0.47 \\
\hline SSR/SST ${ }^{b}(\%)$ & 96 & 93 & 94 & 94 & 94 & 66 & 76 & 83 & 90 & 95 & 96 & 95 \\
\hline RMSE $^{c}$ & 1.7 & 2.1 & 2.0 & 1.6 & 1.0 & 1.0 & 1.0 & 1.1 & 1.0 & 1.3 & 1.4 & 1.7 \\
\hline \multicolumn{13}{|c|}{ Svalbard Airport-Akseløya (2010-12) } \\
\hline$\alpha^{a}$ & 0.973 & 0.985 & 0.919 & 0.879 & 1.083 & 1.059 & 0.878 & 1.115 & 1.100 & 1.179 & 1.166 & 1.072 \\
\hline$C^{\mathrm{a}}$ & -1.13 & -0.92 & -1.25 & -0.95 & 0.62 & 1.10 & 2.36 & 0.28 & -0.66 & -1.28 & -1.08 & -1.16 \\
\hline SSR/SST b $(\%)$ & 94 & 95 & 93 & 85 & 93 & 75 & 53 & 77 & 90 & 93 & 97 & 93 \\
\hline $\mathrm{RMSE}^{\mathrm{c}}$ & 1.6 & 1.6 & 1.7 & 1.8 & 0.9 & 1.0 & 1.1 & 1.1 & 0.9 & 1.1 & 1.0 & 1.5 \\
\hline$\alpha^{a}$ & 0.835 & 0.915 & 0.863 & 0.766 & 0.621 & 0.447 & 0.447 & 0.447 & 0.707 & 0.995 & 0.881 & 0.753 \\
\hline$C^{a}$ & -0.64 & -0.56 & 0.45 & -0.44 & 0.10 & 4.06 & 4.06 & 4.06 & 2.32 & 0.67 & 0.10 & -0.41 \\
\hline SSR/SST b $(\%)$ & 87 & 66 & 89 & 73 & 60 & 36 & 36 & 36 & 60 & 77 & 78 & 85 \\
\hline RMSE $^{\mathrm{c}}$ & 3.0 & 4.2 & 2.3 & 2.4 & 1.7 & $1.7^{d}$ & $1.7^{d}$ & $1.7^{d}$ & 1.4 & 2.1 & 2.7 & 2.2 \\
\hline \multicolumn{13}{|c|}{ Svalbard Airport-Svarttangen (2010-12) } \\
\hline$\alpha^{\mathrm{a}}$ & 0.977 & 0.893 & 0.764 & 0.892 & 0.860 & 0.771 & 0.771 & 0.771 & 1.157 & 1.208 & 0.967 & 0.879 \\
\hline$C^{a}$ & -0.53 & -1.16 & -1.08 & 0.12 & 0.87 & 3.20 & 3.20 & 3.20 & -0.33 & -0.89 & -1.19 & -1.03 \\
\hline SSR/SST ${ }^{b}(\%)$ & 92 & 86 & 88 & 80 & 62 & 33 & 33 & 33 & 75 & 91 & 91 & 90 \\
\hline RMSE $^{\mathrm{c}}$ & 2.4 & 2.7 & 2.5 & 2.1 & 1.7 & $1.8^{d}$ & $1.8^{d}$ & $1.8^{d}$ & 1.1 & 1.3 & 1.8 & 1.8 \\
\hline \multicolumn{13}{|c|}{ Svalbard Airport-Isfjord Radio } \\
\hline$\alpha^{\mathrm{a}}$ & 1.218 & 1.231 & 1.263 & 1.226 & 1.207 & 1.193 & 1.226 & 1.132 & 1.156 & 1.195 & 1.207 & 1.205 \\
\hline$C^{\mathrm{a}}$ & -0.56 & -0.41 & -0.27 & -0.37 & 0.09 & -0.09 & -0.33 & -0.19 & -0.80 & -0.89 & -0.59 & -0.61 \\
\hline $\mathrm{SSR} \mathrm{SST}^{\mathrm{b}}(\%)$ & 96 & 96 & 95 & 94 & 97 & 89 & 79 & 85 & 93 & 96 & 96 & 96 \\
\hline RMSE $^{c}$ & 1.6 & 1.7 & 1.7 & 1.4 & 0.7 & 0.8 & 1.0 & 0.8 & 0.9 & 1.0 & 1.1 & 1.5 \\
\hline \multicolumn{13}{|c|}{ Svalbard Airport-Sørkappøya (2010-12) } \\
\hline$\alpha^{\mathrm{a}}$ & 1.020 & 1.038 & 0.984 & 0.920 & 1.050 & 0.740 & 0.370 & 0.600 & 1.234 & 1.290 & 1.240 & 1.043 \\
\hline$C^{a}$ & -1.71 & -1.64 & -1.84 & -1.27 & 0.84 & 3.00 & 5.83 & 3.73 & -0.81 & -1.88 & -1.97 & -2.14 \\
\hline SSR/SST ${ }^{b}(\%)$ & 90 & 86 & 88 & 84 & 83 & 34 & 1 & 13 & 73 & 86 & 90 & 84 \\
\hline RMSE $^{c}$ & 2.1 & 2.6 & 2.1 & 2.8 & 1.4 & 1.6 & 1.5 & 2.0 & 1.4 & 1.4 & 1.6 & 2.3 \\
\hline \multicolumn{13}{|c|}{${ }^{b}$ Svalbard Airport-grid point $78^{\circ} \mathrm{N}, 16^{\circ} \mathrm{E}$} \\
\hline$\alpha^{\mathrm{a}}$ & 2.327 & 2.666 & 2.212 & 2.334 & 1.492 & 0.751 & 0.679 & 0.630 & 1.047 & 1.388 & 1.986 & 2.272 \\
\hline $\mathrm{C}^{\mathrm{a}}$ & -1.00 & -0.18 & -3.72 & -2.25 & -2.03 & 1.39 & 3.41 & 3.08 & -0.09 & -1.55 & -0.72 & -0.18 \\
\hline SSR/SST ${ }^{b}(\%)$ & 70 & 60 & 56 & 55 & 44 & 34 & 40 & 41 & 73 & 82 & 76 & 73 \\
\hline
\end{tabular}

${ }^{a}$ Coefficients in the regression equation (Eqns. 2, 3). ${ }^{\text {b }}$ The regression SSR divided by the SST in \% (variance accounted for by regression). ${ }^{c}$ Root mean square of the residuals. ${ }^{d}$ Regressions with data for the entire summer season June-August. 

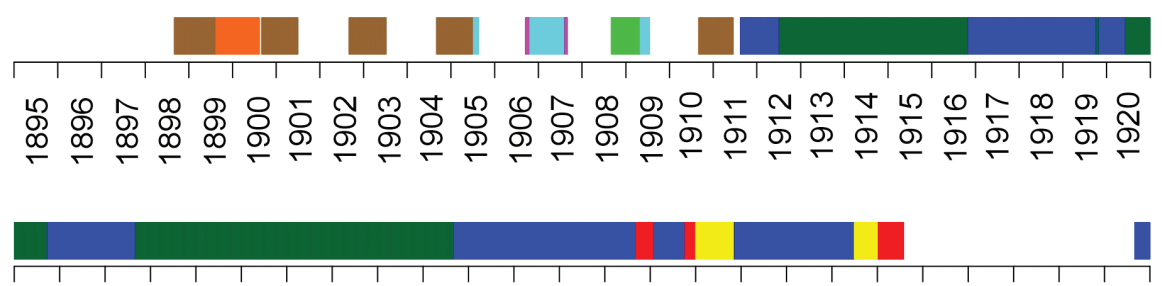

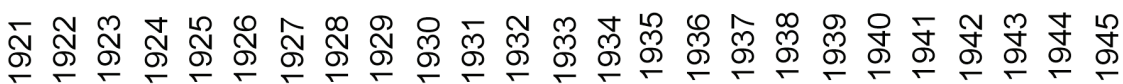

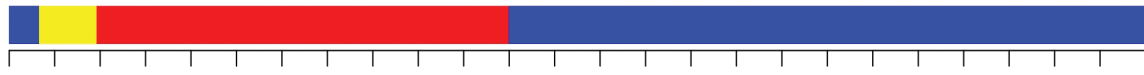

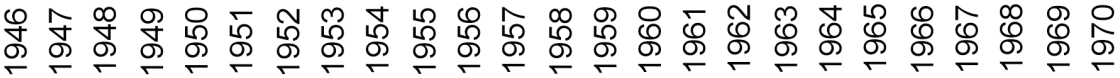

\begin{tabular}{|l|l|l|l|l|l|l|l|l|l|l|l|l|l|l|l|l|l|l|l|l|l|}
\hline &
\end{tabular}

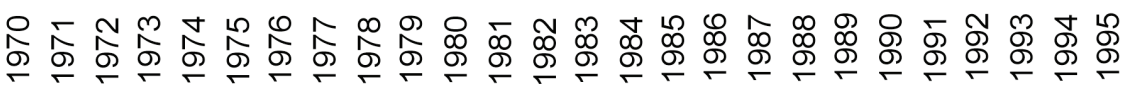

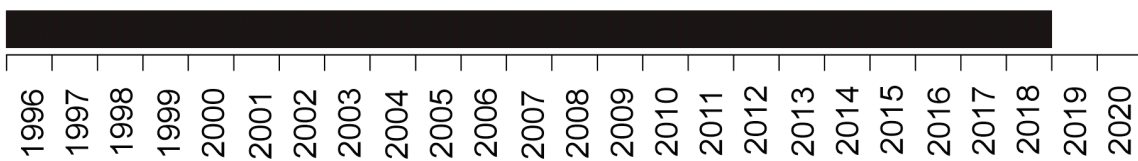

\begin{tabular}{lllll}
99765 Akseløya & 99752 Sørkappøya & 99820 Barentsburg \\
\hline 99928 Crozierpynten & 99860 Longyearbyen & 99790 Isford Radio \\
\hline 99737 Svarttangen & 99821 Green Harbour & 99840 Svalbard Airport \\
99732 Halvmåneøya & &
\end{tabular}

Fig. 2 The nine local series used in the composite Svalbard series. Svalbard Airport is the principle series, indicated in black. The national station identifiers and names of the local series are given in the legend.

\section{Decadal variations}

Decadal variations were studied by low-pass Gaussian filtering (Fig. 3). A striking feature is the warming from the 1910s to the 1930s known as the early 20th century warming, which leads up to the local maxima in the 1930 s and the 1950s. They were particularly warm both for annual and seasonal mean temperature. Another striking feature is the warming of the Svalbard climate in the latest two decades. The present warm Svalbard Airport climate exceeds the temperature of the 1930s and 1950 s by at least $2{ }^{\circ} \mathrm{C}$ for annual values. The most pronounced cold decade was that of the 1910s, which was colder than any other decade in the whole series, and in all seasons. Another cold phase peaked in the 1960s.

\section{Regime shifts}

The decadal variations illustrated by Gaussian filtering, might lead us to presume that the Svalbard temperature climate shifts between different regimes. In the work of Nordli et al. (2014), for the period 1899-2012, six regimes were detected by the Rodionov test (Rodionov 2004) for the annual means, and five regimes were detected for the winter (DJF) means. We performed exactly the same testing on the new data set for the 1899-2012 period and got the same results.

Slightly reducing the influence of outliers by using the Huber tuning constant (Huber 1981; Fig. 4) made the shortest regimes (those in the 1910s and 1960s) disappear, so the number of regimes was reduced to four both for the annual series and for the winter season series. The series begins with a cold regime, the next is warm, then cold again and the last one is warm. For annual means the last cold regime is $1.0{ }^{\circ} \mathrm{C}$ warmer than the first cold regime, and the last warm regime is $1.7^{\circ} \mathrm{C}$ warmer than the first warm regime. This is a consequence of a trend towards higher temperature for the entire series. 

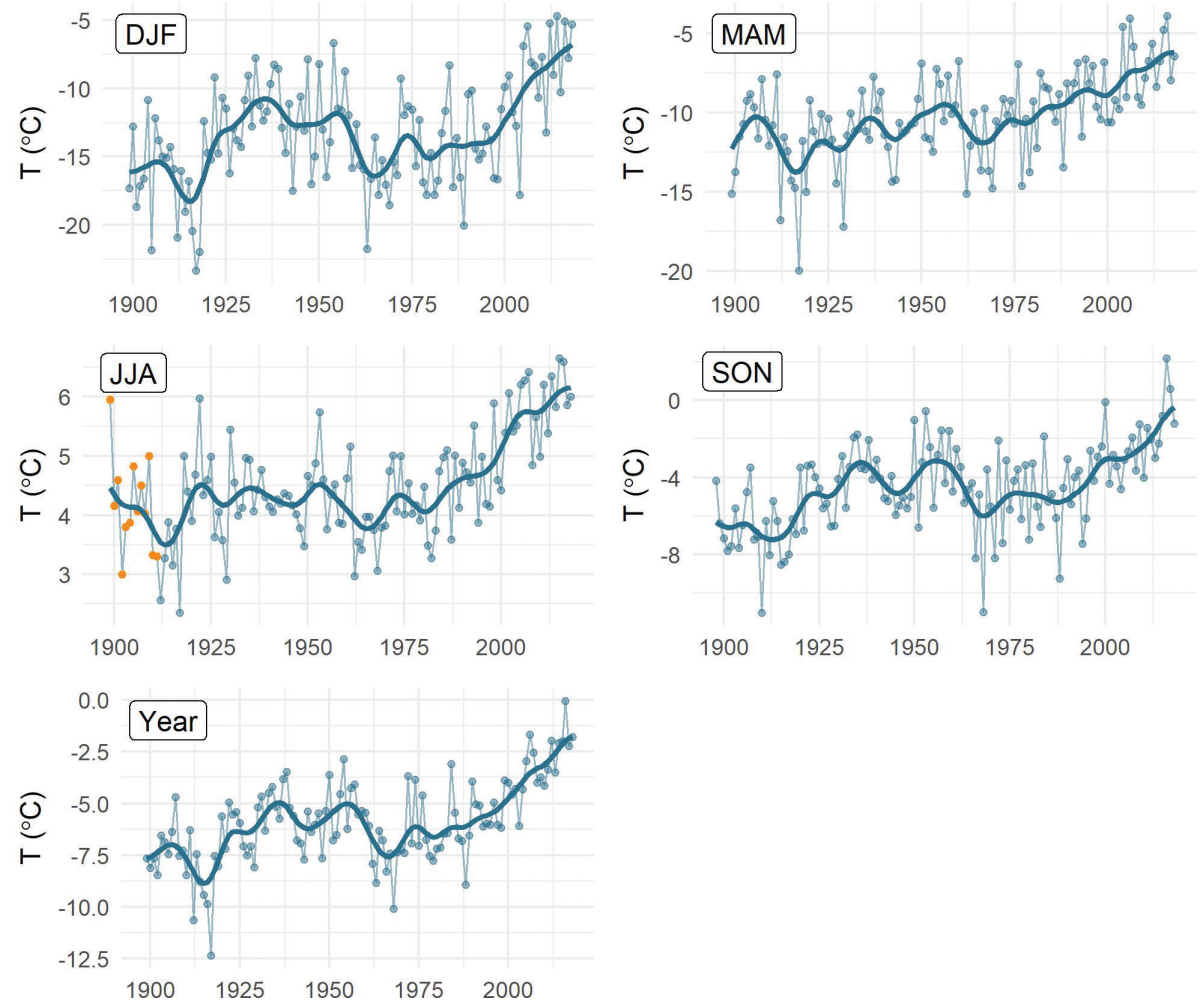

Fig. 3 Temperature $\left({ }^{\circ} \mathrm{C}\right)$, vertical axis for the composite Svalbard Airport series during the period September 1898-December 2018 for winter (DJF), spring (MAM), summer (JJA), autumn (SON) and annual means (Year). Individual years (dots) are filtered by a Gaussian low-pass filter (curve) with a standard deviation of three years in its distribution, corresponding to a rectangular filter of about 10 years. (The ends of the curves are not significant. For the last year, 2018, 38\% of the weights will lie on unknown future observations; for the sixth last year, 2012, it is only 5\%.) Orange dots represent mean temperatures for the summer season; these values have larger uncertainty than the other means.
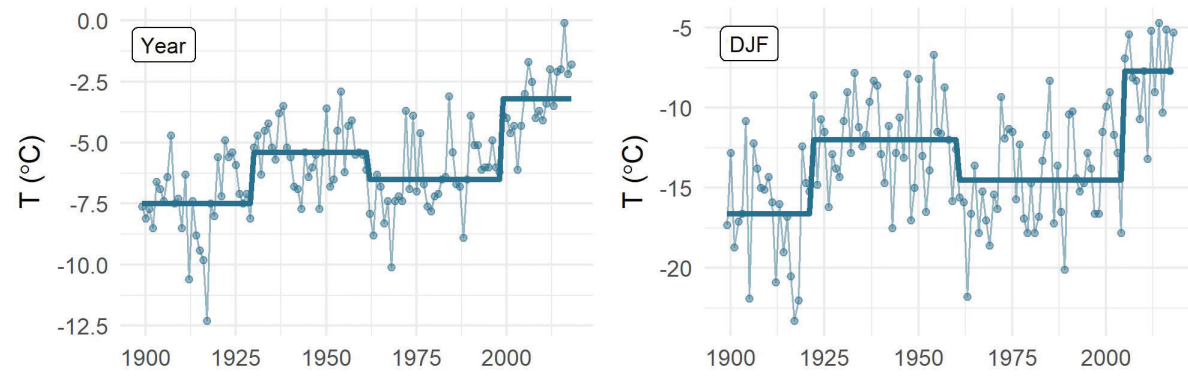

Fig. 4 Regime shifts of the extended Svalbard Airport temperature series detected by using the Rodionov test for annual and winter season means in the period 1899-2018. The shifts were determined by means of Student's test with significance level $p=0.05$, and the cut-off length was set to 10 years. Shifts were detected after data prewhitening procedure by using the IP4 method (see Rodionov 2006) but original data are plotted. Huber's tuning constant was set to 2 .

\section{Trends and statistical significance}

The Svalbard Airport series shows large positive linear trends in all seasons (Table 3). They are greatest in winter and spring with an increase of 0.43 and $0.42{ }^{\circ} \mathrm{C}$ per decade, respectively, compared to $0.13{ }^{\circ} \mathrm{C}$ in summer. The trend in winter is much steeper than in summer but the variability is also much larger. Compared to the other seasons the winter has the steepest trend, but the lowest signal-to-noise ratio, that is, trend divided by standard deviation (Table 3). The trend for annual means amounts to $0.32{ }^{\circ} \mathrm{C}$ per decade. For individual months, the trend is largest in February and smallest in June: 0.65 and $0.10^{\circ} \mathrm{C}$, respectively, per decade (not shown). 
Table 3 Annual and seasonal linear trends and signal to noise ratio (trend divided by standard deviation) in the Svalbard Airport homogenized series for winter (DJF), spring (MAM), summer (JJA) and autumn (SON) for the whole series September 1898-December 2018 and for the period January 1991-December 2018. All trends are significant at the 0.05 level.

\begin{tabular}{llllll}
\hline & Annual & DJF & MAM & JJA & SON \\
\hline Whole series 1898.09-2018.12 & & & & & \\
Trend $\left({ }^{\circ} \mathrm{C}\right)$ per decade & 0.32 & 0.43 & 0.42 & 0.13 & 0.30 \\
Signal to noise ratio & 1.9 & 1.3 & 1.8 & 1.8 & 1.6 \\
Period 1991.01-2018.12 & & & & & \\
Trend $\left({ }^{\circ} \mathrm{C}\right)$ per decade & 1.66 & 3.19 & 1.05 & 0.66 & 1.65 \\
Signal to noise ratio & 3.6 & 8.4 & 4.6 & 1.7 & 4.4 \\
\hline
\end{tabular}

Table 4 Definitions of terms used in threshold statistics.

\begin{tabular}{|c|c|}
\hline Terms & Definitions \\
\hline GD & Number of growing days, $T>5^{\circ} \mathrm{C}$ in May-Sep \\
\hline TD & Number of thawing days, $T>0{ }^{\circ} \mathrm{C}$ in May-Sep \\
\hline MD & Number of melt days, $T>0{ }^{\circ} \mathrm{C}$ in Oct-Apr \\
\hline FD & Number of freeze days, $T<0^{\circ} \mathrm{C}$ in Oct-Apr \\
\hline $\begin{array}{l}\text { Annual growing } \\
\text { degree-days sum }\end{array}$ & $\mathrm{GDD}=\sum_{i=1}^{n} \operatorname{Max}\left(0, T_{i}-5\right)$ for May - Sep \\
\hline $\begin{array}{l}\text { Air thawing index } \\
\text { degree-days sum }\end{array}$ & $\mathrm{ATI}=\sum_{i=1}^{n} \operatorname{Max}\left(0, T_{i}\right)$ for May - Sep \\
\hline $\begin{array}{l}\text { Positive degree-days } \\
\text { sum }\end{array}$ & $\mathrm{PDD}=\sum_{i=1}^{n} \operatorname{Max}\left(0, T_{i}\right)$ for Oct $-\mathrm{Apr}$ \\
\hline $\begin{array}{l}\text { Air freezing index } \\
\text { degree-days sum }\end{array}$ & $\mathrm{AFI}=\sum_{i=1}^{n} \operatorname{Min}\left(0, T_{i}\right)$ for Oct $-\mathrm{Apr}$ \\
\hline$T_{\mathrm{i}}$ & $\begin{array}{l}\text { Mean temperature on day } i \text { and } n \text { is the } \\
\text { number of days }\end{array}$ \\
\hline$n$ & Number of days \\
\hline
\end{tabular}

For the entire period 1899-2018 the temperature has increased by $3.8{ }^{\circ} \mathrm{C}$ for annual means, which might be seen as a manifestation of Arctic amplification. For the homogenized Oslo series (Nordli et al. 2015), for example, the temperature change for the same period is $1.3^{\circ} \mathrm{C}$, whereas the global mean is about $1{ }^{\circ} \mathrm{C}$. The significance of the trends was tested by making use of the MannKendall rank test with $1 \%$ significance level. The trends were significant for annual means as well as for seasonal means in the period 1899 (for autumn 1898)-2018.

Trends in annual and seasonal means (Table 3) can be compared with the corresponding table 4 in the work of Nordli et al. (2014). In all seasons both the trends and the signal-to-noise ratio have increased. For the annual mean, the trend is now $0.32{ }^{\circ} \mathrm{C}$ per decade compared to $0.26{ }^{\circ} \mathrm{C}$. The reason must be either the extra data at the end of the series or the recent digitization and improved data control. We tested this by using the new data set but omitted the six new years (2013-18). The annual trend
(1899-2012) was then the same for the new data set as for the old one, $0.26^{\circ} \mathrm{C}$. For winter, the trend increased by $0.02{ }^{\circ} \mathrm{C}$ and in spring it decreased by $-0.02{ }^{\circ} \mathrm{C}$, whereas there was no change for summer and autumn.

We may conclude that the increased trends are not generated by correction of the old data, but by the increased length of the series. Adding six years of data to the original data set lengthened the data set by only $5 \%$. It may be surprising that this could influence the trends so much, but five of the six years were particularly warm; they are among the seven warmest years in the entire series.

Recent trends in the Spitsbergen temperature climate seem to be very steep as depicted in Fig. 3. This has motivated the decision to conduct a study spanning the latest 28 years (1991-2018), which will be included in the next standard normal period (1991-2020). For all seasons the trends during those years are steeper than for the whole series (Table 3). In particular, the linear trend for the winter season is very steep, amounting to $3.2 \%$ decade. For all seasons, but summer, the signal to noise values are also more pronounced in the recent period compared to the whole series.

\section{Threshold statistics}

The new data set of mean daily temperatures allows us to present long-term threshold statistics for Svalbard, definitions (Table 4) and results (Table 5, Fig. 5). These provide additional information about the Svalbard climate, which may prove useful for biologists and engineers, particularly for thresholds near zero. Figure 5a shows tremendous changes during the last three decades for the number of days per year warmer than the thresholds 0 and $5{ }^{\circ} \mathrm{C}$ and also for days colder than the thresholds -10 and $-20^{\circ} \mathrm{C}$. The 1910s had 26 more days below $-20{ }^{\circ} \mathrm{C}$ compared to the 1961-1990 normal, while the period 1991-2018 had 27 fewer days compared to the same period. In 2014, 2016 and 2018 there were no days colder than $-20^{\circ} \mathrm{C}$.

Long-term variability in GD impacts plants' and animals' activity and growth, which in the Arctic region may start as soon as snow melting has taken place. Thus, both a threshold above $0{ }^{\circ} \mathrm{C}$ (TD) and the conventional $5{ }^{\circ} \mathrm{C}$ (GD) are used for the May-September season (Fig. 5b). The numbers of TD and GD have both increased in recent times. The warming escalated during the period 19912018. The linear trend for 1991-2018 was as strong as 10 days/decade and 14 days/decade for TD and GD, respectively (Table 5).

Warm winter spells have been reported more frequently in Svalbard in recent years (Vikhamar-Schuler et al. 2016; Peeters et al. 2019). Following the work of VikhamarSchuler et al. (2016), the long-term variability in the number 

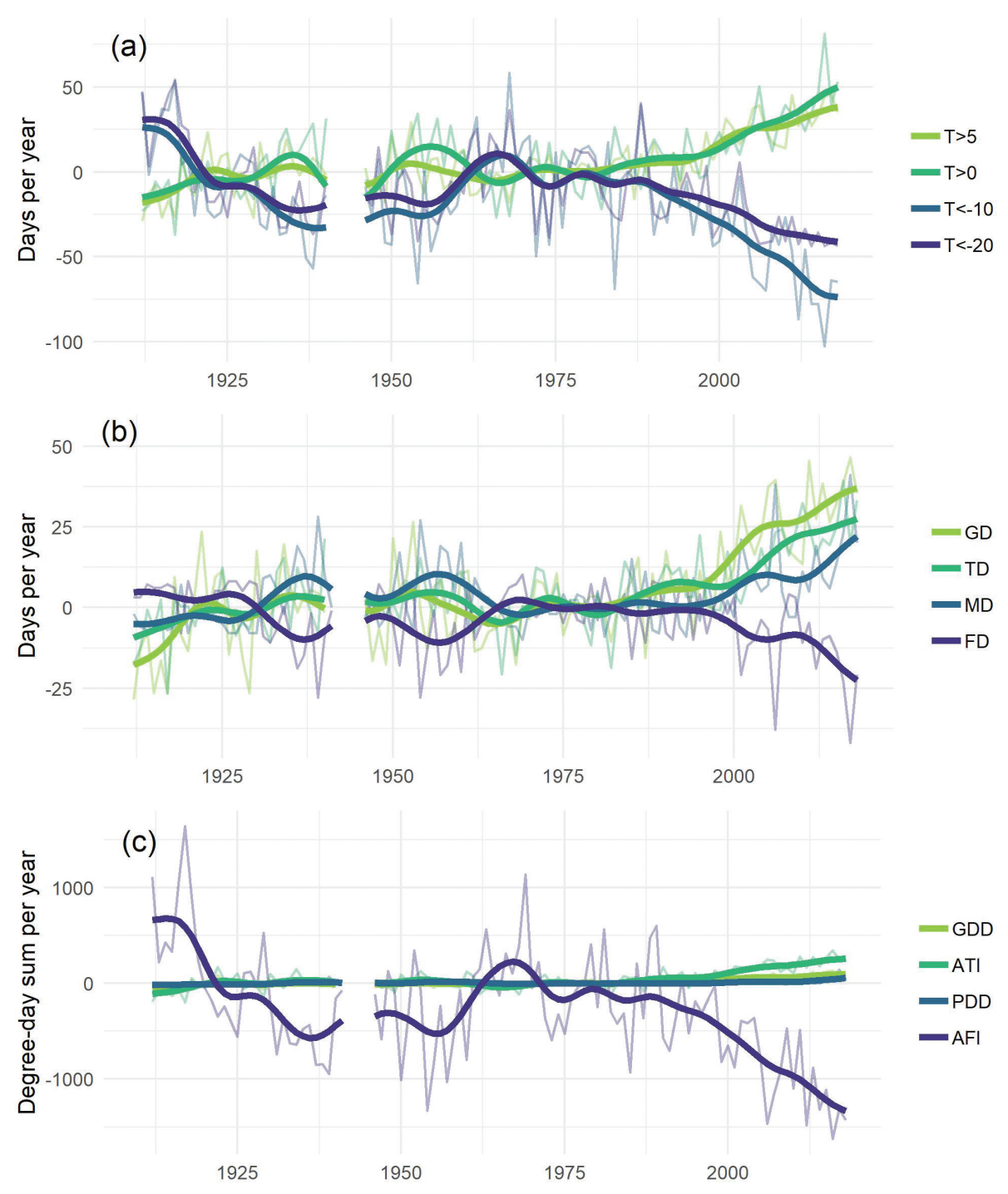

Fig. 5 Long-term daily mean air temperature (T) variability given as anomalies from the 1961-1990 standard normal period. All series are also filtered with a 10-year Gaussian filter. The definitions of GD, TD, MD, FD, GDD, ATI, PDD and AFI are given in Table 4.

of $\mathrm{MD}$ (Fig. 5b) is a useful measure to evaluate changes in the frequency of such winter-warming events in Svalbard. They were also frequent in the 1930s and 1950s and not nearly as frequent as in the latest decades. Consistent with the increase of $\mathrm{MD}$, a decrease in FD is also observed.

Degree-day sums are the sum of the temperatures of the days with daily mean temperatures above or below certain thresholds; so, they are a measure of not only the duration of such events but also their magnitude. The ATI is used in permafrost engineering and is a basis for engineering design and for estimations of active layer thickness over the permafrost (Instanes 2016). The ATI is a measure of both magnitude and duration of the above $0{ }^{\circ} \mathrm{C}$ daily mean temperature during the summer season each year. Likewise, the
GDD measures magnitude and duration of daily mean temperature values above $5{ }^{\circ} \mathrm{C}$ during May to September. There has been a large increase in the GDD and ATI in the period 1991-2018, amounting to an increase of 81 and 35\% compared to the 1961-90 standard normal (Table 5).

To evaluate the intensity of warm events in the cold season spanning October-April, the PDD is used (Fig. 5c, Table 5). In the period 1991-2018, PDD has increased by $94 \%$ compared to the 1961-90 normal. The AFI is a measure of the magnitude and duration of below $0{ }^{\circ} \mathrm{C}$ temperature events during the winter season each year. The results show that the mean AFI for Svalbard Airport has decreased considerably since the late 1980s, the linear trend in the period 1991-2018 amounts to -442 degree-days/decade. 
Table 5 Threshold statistics for the recent period 1991-2018 compared to the standard normal period 1961-1990. Linear trends in the recent period are also given.

\begin{tabular}{|c|c|c|c|c|c|}
\hline Threshold/index & Period1961-1990 & $\begin{array}{c}\text { Period } \\
1991-2018\end{array}$ & $\begin{array}{c}\text { Anomaly } \\
\text { (days or degree-days) }\end{array}$ & $\begin{array}{c}\text { Anomaly } \\
(\%)\end{array}$ & $\begin{array}{c}\text { Trend } \\
\text { 1991-2018 } \\
\text { (days or degree-days/decade) }\end{array}$ \\
\hline$T>5\left({ }^{\circ} \mathrm{C}\right)$ & 37 & 59 & 22 & 59 & 14 \\
\hline$T>0\left({ }^{\circ} \mathrm{C}\right)$ & 118 & 142 & 25 & 21 & 18 \\
\hline$T<-10\left({ }^{\circ} \mathrm{C}\right)$ & 131 & 89 & -42 & -32 & -25 \\
\hline$T<-20\left({ }^{\circ} \mathrm{C}\right)$ & 43 & 16 & -27 & -62 & -12 \\
\hline GD & 37 & 58 & 22 & 59 & 14 \\
\hline TD & 107 & 122 & 16 & 15 & 10 \\
\hline MD & 11 & 20 & 9 & 79 & 8 \\
\hline FD & 201 & 192 & -8 & -4 & -8 \\
\hline GDD & 68 & 123 & 55 & 81 & 34 \\
\hline ATI & 442 & 595 & 153 & 35 & 90 \\
\hline PDD & 20 & 38 & 18 & 94 & 20 \\
\hline $\mathrm{AFI}$ & 2707 & 1947 & -760 & -28 & -442 \\
\hline
\end{tabular}

\section{Discussion}

\section{Improving the series by reducing uncertainty and adding more data}

The methods that generated the first edition of the composite Svalbard Airport series have also been used in the present study. The original series had only monthly resolution, but the monthly values were in most cases generated by taking the arithmetic means of daily series. Therefore, in principle, there should be no differences between the old and new data set of monthly means. However, digitization of the Longyearbyen data series, the established overlapping periods between Isfjord Radio and Svalbard Airport, and the longer overlapping periods with Akseløya and Sørkappøya have led to some changes (see the Metadata subsection for details).

Those metadata changes affect the composite series only before 1948. However, for the annual mean of all years in the period 1898-1947 there are no differences. For the mean temperature of individual months in that period, only April and December are different, but not by more than $0.1{ }^{\circ} \mathrm{C}$. This does not mean that the recent corrections of the old data sets are not important. In the early part of the composite series, there are a few monthly means that have changed a lot (see the difference between the new and old Svalbard Airport composite series in Supplementary Table S3).

\section{Are the regression equations biased?}

Akseløya, Sørkappøya, Svarttangen and Crozierpynten were AWAKE research project stations intended for operation during two years, from summer 2010 to summer 2012. The regression equations for the Svalbard Airport series were performed with daily means grouped by months, so the number of data points in the regressions was only about 60. Fortunately, Axeløya and Sørkappøya were turned into permanent stations in MET Norway's operational network. This has by now increased the number of data points in the regression to about 250 for each month. This increased the significance of the regressions where these two stations were involved, that is, in parts of the 1898-1911 time interval.

Another question that should be addressed is the risk for biased results when regression equations are developed in the present Svalbard climate for reconstruction of the historical climate. If the local climate has changed in the same way at Svalbard Airport as at the local stations, the method should be unbiased. This is assumed when relative homogeneity tests are used (e.g., Nordli et al. 2015).

One possible reason for biased regressions for the composite series is that the ice cover could react differently on the recent temperature increase at Spitsbergen. We know that Isfjorden has had very little ice cover in the $21 \mathrm{st}$ century and that the Svalbard Airport series has greater temperature trends than most other neighbouring series (Gjelten et al. 2016; Isaksen et al. 2016).

If the ice cover has diminished less at the local station than at the Airport, the regressed temperature at the Airport could be too high in the period 1898-1911. The trend back in time to the beginning of the composite series could then be too weak. However, in that period four local stations are used; so biases, if any, should vary by station within the period.

With help of data from Isfjord Radio we performed a case study by comparing regression equations based on the recent short interval September 2014-December 2018, with the intervals based on historical data 
(Supplementary Table S4). When used for the reconstruction of the composite series, the estimates based on the recent data differed only slightly from those based on the historical data set. The method used seems to be robust for changing climate.

\section{Less model skill for summer observations and reanalysis data}

The model did not infer summer temperatures as well as temperatures for the other seasons, as indicated by the part of the variance accounted for by the regression (Table 2 ). The uncertainties are particularly great for the series from outside western Spitsbergen: Crozierpynten and Svarttangen. (The same is also true for Sørkappøya, but no summer temperature from this station is included in the Svalbard Airport composite series.) We keep the data from Crozierpynten and Svarttangen in the composite series of monthly means but omit them in the corresponding series of daily means because of the large uncertainty.

Before 1911 and during the Second World War there are some missing observations in Svalbard. The monthly values were interpolated by data from reanalysis (Compo et al. 2011) but the model skill is poor (Table 2). Again, we keep the monthly means based on reanalysis but the large uncertainty prompts us to omit the reanalysis data in the series of daily means.

\section{Comparing the composite Svalbard Airport temperature series with the nearest neighbouring series}

Svalbard Airport's neighbouring long-term series are Bjørnøya $\left(74^{\circ} 31^{\prime} \mathrm{N}, 19^{\circ} 00^{\prime} \mathrm{E}\right)$, to the south of Spitsbergen, Vardø $\left(70^{\circ} 22^{\prime} \mathrm{N}, 31^{\circ} 6^{\prime} \mathrm{E}\right)$, in north-eastern continental Norway, Jan Mayen $\left(70^{\circ} 56^{\prime} \mathrm{N}, 8^{\circ} 40^{\prime} \mathrm{W}\right)$, between Iceland and Svalbard and Malye Karmakuly $\left(72^{\circ} 22^{\prime} \mathrm{N}, 52^{\circ} 42^{\prime} \mathrm{E}\right)$, in the Russian archipelago of Novaya Zemlya. These meteorological stations are situated in the North Atlantic and Barents Sea. All of them are positively correlated with the Svalbard Airport series for annual and seasonal mean temperature (Przybylak 1997, 2016) during the years when they overlap with the Svalbard Airport series. With correlations of about 0.9 for annual values and for winter, spring and autumn, the Svalbard series is most closely in tandem with the Bjørnøya series than the other stations (Supplementary Table S5). This is also true for post-1950 sub-periods but not for the warm period of 1921-50, where correlations are somewhat weaker. The correlations for annual values during the period 1921-2018 are 0.94 for Bjørnøya, 0.81 for Jan Mayen, 0.75 for Vardø and 0.66 for Malye Karmakuly.
Different sub-periods have seen different temperature trends in the Svalbard Airport series (Fig. 3). The warming in the early 20th century and the following cold period are striking examples. The four other stations in the area also follow this pattern but the magnitudes of the trends are different (Supplementary Table S6). Svalbard Airport and Malye Karmakuly have had the strongest temperature decrease during the period 1951-80 but also the strongest increase in the recent 1991-2018 period (Supplementary Table S6). Finally, we can conclude that the Svalbard Airport series exhibits a stronger trend during the common data period, 1921-2018, than the other four stations.

\section{The recent warming of Svalbard and implications from long-term threshold statistics}

The reason for the large decadal variations in air temperature in Svalbard might to a certain extent be governed by temperature variability in the North Atlantic Ocean, such as the Atlantic multidecadal oscillation (Hanssen-Bauer et al. 2019 and references therein). It is supposed that this is the main reason for the detected regime shifts in the Svalbard Airport series. The inflow of Atlantic Water to the Svalbard region was particularly high after around 2000. This is consistent with a detected shift to high temperature in 1999 for annual temperature and in 2005 for the winter season.

The recent increase in surface air temperature in Svalbard is the greatest observed in Europe (Nordli et al. 2014) and among the most severe in the Arctic during the last three decades (Isaksen et al. 2016). Since 1991, the rate of warming at Svalbard Airport has been $1.7{ }^{\circ} \mathrm{C} /$ decade, based on linear trend analysis (Table 3 ). This amounts to more than twice the Arctic average $\left(0.8^{\circ} \mathrm{C} /\right.$ decade, north of $66^{\circ} \mathrm{N}$ (NOAA-ESRL 2019) and is about seven times the global average $\left(0.2{ }^{\circ} \mathrm{C} /\right.$ decade $)$, based on the latest GISTEMP data (GISTEMP Team 2019; Lenssen et al. 2019). In a recent paper, Przybylak \& Wyszyński (2020) inferred that the annual mean temperature for the High Arctic (see definition in their figure 1) has increased by $1.6{ }^{\circ} \mathrm{C}$ in the period 1996-2015 compared with the reference period 1951-1990. For Svalbard Airport, the comparable increase amounts to $2.5^{\circ} \mathrm{C}$, that is, $0.9{ }^{\circ} \mathrm{C}(56 \%)$ higher than for the High Arctic.

Mechanisms for Arctic amplification are still debated, but feedbacks from the loss of sea ice form one of the major components (Overland et al. 2018; IPCC 2019). In mid-winter, sea ice normally covers most of the Arctic Ocean and the northern areas of the five marginal Arctic seas. The exceptions in recent years have been the Svalbard area and the northern Barents Sea, which add to the trend towards more open water in winter in this region. These changes are a key to why this region is warming faster than the rest of the Arctic. In Svalbard, the greatest contribution to the recent warming is associated with 
wintertime cyclonic air advection from the east-northeast, related to a low-pressure system moving into the Barents Sea (Isaksen et al. 2016). These air masses are strongly modified when they flow over open ocean. Thus, at least parts of the atmospheric warming observed in Svalbard are driven by heat exchange from declining sea ice in the Barents Sea and the region north of Svalbard.

Svalbard Airport's proximity to Isfjorden might be another factor for its severe temperature changes (Gjelten et al. 2016; Isaksen et al. 2016). The fjord has recently become more influenced by the intrusion of warm Atlantic Water from the West Spitsbergen Current (Cottier et al. 2007; Nilsen et al. 2008), which plays a decisive role for the sea-ice cover in the fjord and thereby increases heat exchange from the larger open water areas even during winter.

Although not as severe as the air advection from the eastnorth-east, a general warming is seen for all atmospheric circulation types in Svalbard (Isaksen et al. 2016), suggesting additional contributions from large-scale mechanisms, such as general background warming (Bindoff et al. 2013; Fyfe et al. 2013; Pithan \& Mauritsen 2014; Navarro et al. 2016) and higher sea-surface temperatures (Dmitrenko et al. 2014; Carmack 2015). According to a new study conducted by Lind et al. (2018) the increased sea-surface and ocean temperatures in the northern Barents Sea are linked to a recent decline in sea-ice import and a corresponding loss in surface freshwater, leading to weakened ocean stratification, enhanced vertical mixing and increased upward fluxes of heat and salt that prevent sea-ice formation.

The new data set of mean daily temperatures allows us to present long-term threshold statistics for Svalbard (Table 5, Fig. 5). We anticipate that this additional information about Svalbard's climate will be of value to biologists and engineers, particularly for thresholds near zero. The combination of decreasing AFI and increasing ATI is a clear signal of a changing climate, which may affect the stability of existing building foundations on permafrost in Svalbard (Instanes 2016). These events cause ecological disturbance (Peeters et al. 2019); for example, ground-ice formation due to winter rain or melting snow prevents ungulates from grazing (Hansen et al. 2014). They also pose challenges for human society and the archipelago's infrastructure, particularly on account of rising soil temperatures (Hansen et al. 2014).

\section{Conclusions}

The Svalbard Airport composite time series of mean monthly temperature has been widely used by scientists in a variety of disciplines. The present study increases the resolution from a monthly to daily basis, further contributing to scientific studies of Svalbard and the wider Arctic. A Svalbard series on daily resolution opens up for calculating threshold statistics that is necessary for, for example, engineering design and biological research on the islands. The large changes in the Svalbard climate during the last 30 years, which by this long-term series sets in a historical context, makes this of paramount interest. Our study supports the concept that the Svalbard climate responds to increasing greenhouse gases in the atmosphere with a series of regime shifts. These are governed by a combination of natural variability and a set of feedbacks that amplify warming, especially related to changing sea-surface temperature and sea-ice variations. Four shifts were detected, indicating that the temperature was alternating between warm and cold phases. Alternatively, the variations in the series can be interpreted as variations on a multi-decadal scale, consisting of positive and negative local trends. For the whole series, 1899-2018, the linear increase was $3.8^{\circ} \mathrm{C}$. That is about 3.5 times more than for the global mean temperature during the same period.

\section{Acknowledgements}

The authors acknowledge Olav P. Amundgård for digitizing the previously missing protocols from the Longyearbyen station.

\section{Disclosure statement}

The authors report no conflict of interest

\section{Funding}

The research work of E€, TN, ØN, RP and PW was supported by a grant entitled Causes of the Early 20th Century Arctic Warming, funded by the National Science Centre, Poland (grant no. 2015/19/B/ST10/02933). The project stations Akseløya, Svarttangen, Crozierpynten and Sørkappøya were funded by the Polish-Norwegian Research Fund and Norway Grants, AWAKE project PNRF-22-A I-1/07 (Arctic Climate and Environment of the Nordic Seas and the Svalbard-Greenland Area).

\section{References}

AMAP (Arctic Monitoring and Assessment Programme) 2017. Snow, Water, Ice and Permafrost in the Arctic (SWIPA) 2017. Oslo: Arctic Monitoring and Assessment Programme.

Alekseev G., Glok N. \& Smirnov A. 2016. An assessment of the relationship between changes of sea ice extent and climate in the Arctic. International Journal of Climatology 36, 3407-3412, doi: 10.1002/joc.4550.

Alexandersson H. 1986. A homogeneity test applied to precipitation data. Journal of Climatology 6, 661-675, doi: 10.1002/joc. 3370060607 . 
BACC (BALTEX Assessment of Climate Change for the Baltic Sea Basin) Author Team 2008. Assessment of climate change for the Baltic Sea basin. Berlin: Springer.

Bindoff N.L., Stott P.A., AchutaRao K.M., Allen M.R., Gillett N., Gutzler D., Hansingo K., Hegerl G., Hu Y., Jain S., Mokhov I.I., Overland J., Perlwitz J., Sebbari R. \& Zhang $X$. 2013. Detection and attribution of climate change: from global to regional. In T.F. Stocker et al. (eds.): Climate change 2013: the physical science basis. Contribution of Working Group I to the fifth assessment report of the Intergovernmental Panel on Climate Change. Pp. 867-952. Cambridge: Cambridge University Press.

Carmack E. 2015. Toward quantifying the increasing role of oceanic heat in sea ice loss in the new Arctic. Bulletin of the American Meteorological Society 96, 2079-2105, doi: 10.1175/ BAMS-D-13-00177.1.

Compo G.P., Whitaker J.S., Sardeshmukh P.D., Matsui N., Allan R.J., Yin X., Gleason B.E., Vose R.S., Rutledge G., Bessemoulin P., Brönnimann S., Brunet M., Crouthamel R.I., Grant A.N., Groisman P.Y., Jones P.D., Kruk M.C., Kruger A.C., Marshall G.J., Maugeri M., Mok H.Y., Nordli Ø., Ross T.F., Trigo R.M., Wang X.L., Woodruff S.D. \& Worley S.J. 2011. The twentieth century reanalysis project. Quarterly Journal of the Royal Meteorological Society 137, 1-28, doi: 10.1002/qj.776.

Corti S., Molteni F. \& Palmer T.N. 1999. Signature of recent climate change in frequencies of natural atmospheric circulation regimes. Nature 398, 799-802, doi: 10.1038/19745.

Cottier F.R., Nilsen F., Inall M.E., Gerland S., Tverberg V. \& Svendsen H. 2007. Wintertime warming of an Arctic shelf in response to large-scale atmospheric circulation. Geophysical Research Letters 34, L10607, doi: 10.1029/2007GL029948.

Descamps S., Aars J., Fuglei E., Kovacs K.M., Lydersen C., Pavlova O., Pedersen Å.Ø., Ravolainen V. \& Strøm H. 2017. Climate change impacts on wildlife in a High Arctic archipelago-Svalbard, Norway. Global Change Biology 23, 490-502, doi: 10.1111/gcb.13381.

Dmitrenko I.A., Kirillov S.A., Serra N., Koldunov N.V., Ivanov V.V., Scauer U., Polyakov I.V., Barber D., Janout M., Lien V.S., Makhotin M. \& Aksenov Y. 2014. Heat loss from the Atlantic Water layer in the northern Kara Sea: causes and consequences. Ocean Science 10, 719-730, doi: 10.5194/os-10-719-2014.

Ewertowski M.W., Evans D.J.A., Roberts D.H., Tomczyk A.M., Ewertowski W. \& Pleksot K. 2019. Quantification of historical landscape change on the foreland of a receding polythermal glacier, Hørbyebreen, Svalbard. Geomorphology 325, 40-54, doi: 10.1016/j.geomorph.2018.09.027.

Fyfe J.C., von Salzen K, Gillett N.P., Arora V.K., Flato G.M. \& McConnell J.R. 2013. One hundred years of Arctic surface temperature variation due to anthropogenic influence. Scientific Reports 3, article no. 2645, doi: 10.1038/srep02645.

GISTEMP Team 2019. GISS Surface Temperature Analysis (GISTEMP). NASA Goddard Institute for Space Studies. Data set accessed on the internet at data.giss.nasa.gov/ gistemp/ on 18 November 2019.

Gjelten H.M., Nordli Ø., Isaksen K., Førland E.J., Sviashchennikov P.N., Wyszynski P., Prokhorova U.V., Przybylak R., Ivanov B.V. \& Urazgildeeva A.V. 2016. Air temperature variations and gradients along the coast and fjords of western Spitsbergen. Polar Research 35, article no. 29878, doi: 10.3402/polar.v35.29878.

Graversen R.G., Langen P.L. \& Mauritsen T. 2014. Polar amplification in CCSM4: contributions from the lapse rate and surface albedo feedbacks. Journal of Climate 27, 44334450, doi: 10.1175/JCLI-D-13-00551.1.

Hamilton C.D., Kovacs K.M. \& Lydersen C. 2018. Individual variability in diving, movement and activity patterns of adult bearded seals in Svalbard, Norway. Scientific Reports 8, article no. 16988, doi: 10.1038/s41598-018-35306-6.

Hansen B.B., Isaksen K., Benestad R., Kohler J., Pedersen Å.Ø., Loe L.E., Coulson S.J., Larsen J.O. \& Varpe Ø. 2014. Warmer and wetter winters: characteristics and implications of an extreme weather event in the High Arctic. Environmental Research Letters 9, article no. 114021, doi: 10.1088/1748-9326/9/11/114021.

Hanssen-Bauer I., Førland E.J., Hisdal H., Mayer S., Sandø A.B. \& Sorteberg B. 2019. Climate in Svalbard 2100-a knowledge base for climate adaptation. NCCS Report 1. Oslo: Norwegian Centre for Climate Services.

Hegerl G.C., Brönnimann S., Schurer A. \& Cowan T. 2018. The Early 20th Century Warming: anomalies, causes, and consequences. Wiley Interdisciplinary Reviews Climate Change 9, e522, doi: 10.1002/wcc.522.

Huber P.J. 1981. Robust statistics. New York: John Wiley.

Instanes A. 2016. Incorporating climate warming scenarios in coastal permafrost engineering design-case studies from Svalbard and northwest Russia. Cold Regions Science and Technology 131, 76-87, doi: 10.1016/j.coldregions.2016.09.004.

IPCC (Intergovernmental Panel on Climate Change) 2019. Summary for policymakers. In H.-O. Pörtner et al. (eds.): IPCC special report on the ocean and cryosphere in a changing climate. Accessed on the internet at https://www.ipcc.ch/srocc/ chapter/summary-for-policymakers/ on 25 March 2020

Isaksen K., Nordli Ø., Førland E.J., Lupikasza E., Eastwood S. $\delta$ Niedzwiedz T. 2016. Recent warming on Spitsbergeninfluence of atmospheric circulation and sea ice cover. Journal of Geophysical Research-Atmospheres 121, 1191311931, doi: 10.1002/2016JD025606.

Lenssen N., Schmidt G., Hansen J., Menne M., Persin A., Ruedy R. \& Zyss D. 2019. Improvements in the GISTEMP uncertainty model. Journal of Geophysical Research-Atmospheres 124, 6307-6326, doi: 10.1029/2018JD029522.

Lind S., Ingvaldsen R.B. \& Furevik T. 2018. Arctic warming hotspot in the northern Barents Sea linked to declining sea-ice import. Nature Climate Change 8, 634-639, doi: 10.1038/s41558-018-0205-y.

Łupikasza E.B. \& Niedźwiedź T. 2019. The influence of mesoscale atmospheric circulation on Spitsbergen air temperature in periods of Arctic warming and cooling. Journal of Geophysical Research-Atmospheres 124, 5233-5250, doi: 10.1029/2018JD029443.

Muckenhuber S., Nilsen F., Korosov A. \& Sandven S. 2016. Sea ice cover in Isfjorden and Hornsund, Svalbard (20002014) from remote sensing data. The Cryosphere 10, 149158, doi: 10.5194/tc-10-149-2016.

Navarro J.C., Varma V., Riipinen I., Seland Ø., Kirkevåg A., Struthers H., Iversen T., Hansson H.-C. \& Ekman A.M.L. 
2016. Amplification of Arctic warming by past air pollution reductions in Europe. Nature Geoscience 9, 277-281, doi: 10.1038/ngeo2673.

Nilsen F., Cottier R., Skogseth R. \& Mattsson S. 2008. Fjordshelf exchanges controlled by ice and brine production: the interannual variation of Atlantic Water in Isfjorden, Svalbard. Continental Shelf Research 28, 1838-1853, doi: 10.1016/j.csr.2008.04.015.

NOAA-ESRL (National Oceanic and Atmospheric Administration Earth System Research Laboratory) 2019. NCEP/NCAR Reanalysis. Physical Sciences Division, Boulder Colorado. Data set accessed on the internet at https://www.google.com/search?q=0.8\% C2\%B0C $\% 2$ Fdecade $\% 2 \mathrm{C}+$ north + of $+66 \% \mathrm{C} 2 \% \mathrm{~B} 0 \mathrm{~N}+(\mathrm{NOAA}-\mathrm{ES}-$ $\mathrm{RL}+20198 \mathrm{rlz}=1 \mathrm{Cl}$ GCEA_enNO $835 \mathrm{NO} 8358 \mathrm{o}-$ $\mathrm{q}=0.8 \% \mathrm{C} 2 \%$ B0C $\% 2$ Fdecade $\% 2 \mathrm{C}+$ north + of $+66 \% \mathrm{C} 2 \% \mathrm{~B}-$ $0 \mathrm{~N}+(\mathrm{NOAA}-\mathrm{ESRL}+20198 \mathrm{gaqs}=$ chrome. $.69 \mathrm{i} 57 \mathrm{j} 69 \mathrm{i} 58$. 5381 j0j78sourceid=chrome\&ie $=$ UTF- 8 on 4 April 2020

Nordli Ø., Hestmark G., Benestad R.E. \& Isaksen K. 2015. The Oslo temperature series 1837-2012: homogeneity testing and temperature analysis. International Journal of Climatology 35, 3486-3504, doi: 10.1002/joc.4223.

Nordli Ø., Przybylak R., Ogilvie A.E.J. \& Isaksen K. 2014. Long-term temperature trends and variability on Spitsbergen: the extended Svalbard Airport temperature series, 1898-2012. Polar Research 33, article no. 21349, doi: 10.3402/polar.v33.21349.

Osmont D., Wendl I.A., Schmidely L., Sigl M., Vega C.P., Isaksson E. \& Schwikowski M. 2018. An 800-year high-resolution black carbon ice core record from Lomonosovfonna, Svalbard. Atmospheric Chemistry and Physics 18, 1277712795, doi: 10.5194/acp-18-12777-2018.

Overland J.E., Hanna E., Hanssen-Bauer I., Kim S.-J., Walsh J.E., Wang M., Bhatt U.S. \& Thoman R.L. 2018. Arctic report card 2018. Accessed on the internet at www.arctic. noaa.gov/Report-Card on 25 March 2020.

Overland J.E. \& Wang M. 2010. Large-scale atmospheric circulation changes are associated with the recent loss of Arctic sea ice. Tellus A 62, 1-9, doi: $10.1111 /$ j.1600-0870.2009.00421.x.

Overland J.E., Wood K. \& Wang M. 2011 . Warm Arctic-cold continents: climate impacts of the newly open Arctic Sea. Polar Research 30, article no. 15787, doi: 10.3402/polar. v30i0.15787.

Overland J.E. \& Serreze M.C. 2012. Advances in Arctic atmospheric research. In P. Lemke \& H.-W. Jacobi (eds.): Arctic climate change. The ACSYS decade and beyond. Pp. 11-26. Dordrecht: Springer.

Park D.-S.R., Lee S. \& Feldstein S.B. 2015. Attribution of the recent winter sea ice decline over the Atlantic sector of the Arctic Ocean. Journal of Climate 28, 4027-4033, doi: 10.1175/JCLI-D-15-0042.1.

Peeters B., Pedersen Å.Ø., Loe L.E., Isaksen K., Veiberg V., Stien A., Kohler J., Gallet J.-C., Aanes R. \& Hansen B.B. 2019. Spatiotemporal patterns of rain-on-snow and basal ice in High Arctic Svalbard: detection of a climate-cryosphere regime shift. Environmental Research Letters 14, article no. 015002, doi: 10.1088/1748-9326/aaefb3.

Pithan F. \& Mauritsen T. 2014. Arctic amplification dominated by temperature feedbacks in contemporary climate models. Nature Geoscience 7, 181-184, doi: 10.1038/NGEO2071.

Pramanik A., van Pelt W., Kohler J. \& Schuler T.V. 2018. Simulating climatic mass balance, seasonal snow development and associated freshwater runoff in the Kongsfjord basin, Svalbard (1980-2016). Journal of Glaciology 64, 943-956, doi: $10.1017 /$ jog.2018.80.

Przybylak R. 1997. Spatial variation of air temperature in the Arctic in 1951-1990. Polish Polar Research 18, 41-63.

Przybylak R. 2016. The climate of the Arctic. 2nd edn. Dordrecht: Springer, doi: 10.1007/978-3-319-21696-6.

Przybylak R. \& Wyszyński P. 2020. Air temperature changes in the Arctic in the period 1951-2015 in the light of observational and reanalysis data. Theoretical and Applied Climatology 139, 75-94, doi: 10.1007/s00704-019-02952-3.

Rodionov S.N. 2004. A sequential algorithm for testing climate regime shifts. Geophysical Research Letters 31, L0924, doi: 10.1029/2004GL019448.

Rodionov S.N. 2006. Use of prewhitening in climate regime shift detection. Geophysical Research Letters 33, L12707, doi: 10.1029/2006GL025904.

Serreze M.C., Barrett A.P. \& Cassano J.J. 2011. Circulation and surface controls on the lower tropospheric air temperature field of the Arctic, Journal of Geophysical Research-Atmospheres 116, D07104, doi: 10.1029/2010JD015127.

Stuecker M.F, Bitz C.M., Armour K.C., Proistosescu C., Kang S.M., Xie S.-P., Kim D., McGregor S., Zhang W., Zhao S., Cai W., Dong Y. \& Jin F.-F. 2018. Polar amplification dominated by local forcing and feedbacks. Nature Climate Change 8, 1076-1081, doi: 10.1038/s41558-018-0339-y.

Vikhamar-Schuler D., Isaksen K., Haugen J.E., Tømmervik H., Luks B., Schuler T.V. \& Bjerke J.W. 2016. Changes in winter warming events in the Nordic Arctic region. Journal of Climate 29, 6223-6244, doi: 10.1175/JCLI-D-15-0763.1.

Wilks D.S. 1995. Statistical methods in the atmospheric science. An introduction. Amsterdam: Academic Press.

Woelders L., Lenaerts J.T.M., Hagemans K., Akkerman K., van Hoof T.B. \& Hoek W.Z. 2018. Recent climate warming drives ecological change in a remote High-Arctic lake. Scientific Reports 8, article no. 6858, doi: 10.1038/ s41598-018-25148-7. 